\title{
Amazon freshwater crab Dilocarcinus pagei (Decapoda: Trichodactylidae): a view about burrow construction behavior
}

\author{
Leandro S. Fernandes ${ }^{1}$, Bruno S. Sant'Anna ${ }^{2}$ \& Gustavo Y. Hattori ${ }^{2}$ \\ ${ }^{1}$ Institute of Exact Sciences and Technology, Federal University of Amazonas \\ Itacoatiara, AM, Brazil \\ ${ }^{2}$ Institute of Exact Sciences and Technology, Federal University of Amazonas, Itacoatiara \\ AM, Brazil. Graduate Program in Science and Technology for Amazon Resources \\ Corresponding author: Leandro Siqueira Fernandes (siqueirafernandes22@gmail.com)
}

\begin{abstract}
Crabs use burrows to prevent predation, environmental interference and shelter. The present study investigated the excavation behavior of the trichodactylid crab Dilocarcinus pagei, considering the biometric aspects of the burrows, the excavation time, the amount of bioturbation and the excavation behavior of the two sexes. The burrows of males had a mean diameter larger than the females, although the depth was similar for both sexes. Females had higher bioturbation than males, and showed enlargement in a camera format at the bottom, even closing the entrance of the burrows with a "plug" after their construction. Both the camera and the presence of the "plug" in the burrows of the females may be associated with reproduction. The presence of pellets observed at the entrance of burrows is associated with the cleaning of the pereiopods by crabs after the excavation. The sequence of behaviors for the construction of the burrows is described in detail, contributing to the knowledge about the biology and ecology of freshwater crabs of the Amazon.
\end{abstract}

Keywords: Dilocarcinus pagei; Decapoda; sediment; crab behavior; Neotropical region; Amazon basin

\section{INTRODUCTION}

Animals may present different behaviors during their life stages, among them the excavation behavior developed by crustaceans, mainly marine (Crane, 1975), mangrove (Nordhaus et al., 2009; Pülmanns et $a l ., 2016)$ and freshwater crabs (Sinha \& Pati, 2008). The excavation behavior allows the soil to movement, promoting bioturbation (Meysman et al., 2006). This soil movement during the construction of the burrows influences directly the sediment texture (Botto \& Iribarne, 2000; Kristensen, 2008), nutrient cycling (Wang et al., 2010) and increases the contact of the soil surface with air, benefiting the growth of microorganisms (Bertness, 1985). In addition to facilitating soil water flow by providing nutrient transport (Ridd, 1996), chemicals such as oxygen, iron, sulfur (Ferreira et al., 2007), carbon and nitrogen are available to plants in the mangrove environments (Botto et al., 2005; Natálio et al., 2017).

The crabs excavate burrows with different shapes and sizes (Gusmão-Junior et al., 2012). These structures can be shaped like chimneys (Shih et al., 2005), hoods (Christy et al., 2001; Ribeiro et al., 2006) or pillars (Mokhlesi et al., 2011). The construction of the burrows may be influenced by the reproductive period (Christy, 1982; Christy et al., 2001; Shih et al., 2005), environmental interference (Chakrabarti, 1981; Christy, 1982) and predation (Koga et al., 2001). The morphology of the burrows ranges from simple (Christy, 1982) to complex (Chakrabarti, 1981; Lim et al., 2015). Also, the burrows are attributes that serve as criteria for choosing partners (Backwell \& Passmore, 1996; Ribeiro et al., 2006; Heatwole et al., 2018).

The crab Dilocarcinus pagei is an important member of the trophic chain, acting as an omnivore, predator and opportunist (Williner \& Collins, 2002). This crab forms part of the bird diet (Magalhães, 1990; Olmos et al., 2006) and inhabits rivers, lakes, ravines, macrophytes (Magalhães, 2003; Taddei \& Herrera, 2010) and burrows (Pinheiro \& Taddei, 2005; Melchor et al., 2010; Genise, 2017). Despite its ecological importance, information on the behavior of $D$. pagei is still limited. Sant'Anna et al. (2014) described 
the daily activity and substrate preference; Senkman et al. (2015) investigated the reproductive behavior of $D$. pagei in populations in Argentina. The present study investigated the excavation behavior of D. pagei, analyzing this aspect in a population from the Central Amazon region, taking into account biometric aspects of the burrows, the time of excavation, the amount of bioturbation and the excavation behavior of both sexes.

\section{MATERIALS AND METHODS}

\section{Burrows built in the environment}

For the investigations of the biometric characteristics of burrows constructed naturally by males and females of the freshwater crab Dilocarcinus pagei, 32 crabs were captured (15 males and 17 females). The crabs were collected between September and October 2015 around Poranga Lake in Itacoatiara, Amazonas, Brazil $\left(03^{\circ} 07^{\prime} 12.9^{\prime \prime} \mathrm{S}, 58^{\circ} 27^{\prime} 6.5^{\prime \prime} \mathrm{W}\right)$. This region is a characteristic area of várzea of the Amazon floodplain, which is completely flooded during the rainy season and becomes dry during the dry season (Junk, 1984).

The collections were carried out by three people for two hours during both day and night. The animals were collected by hand under vegetation and within burrows. A machete was used to aid the excavation. Once captured, the crabs were placed individually in plastic boxes for $12 \mathrm{~h}(18: 00$ to $6: 00 \mathrm{~h})$. Six translucent plastic boxes $(42 \times 28 \times 38 \mathrm{~cm})$ with the bottoms removed were used as a bulkhead and fixed $3 \mathrm{~cm}$ deep in the sediment. Only crabs with all body appendages were used in the experiment.

The excavation behavior was recorded during the experiment that lasted $12 \mathrm{~h}$. All excavated sediment, including balls formed at the entrance of the burrows, were carefully removed with the aid of tweezers, brushes and spoons to avoid deformations. Ten sediment pellets from each crab were randomly collected and brought carefully to the laboratory for measurement. All substrate resulting from the excavation was subjected to granulometric analysis: the sediments excavated from the burrows of males and females were dried in an oven at $105^{\circ} \mathrm{C}$ for three hours to remove moisture from the sediment until reaching a constant weight. The dry sediment was sieved in six sieves, with diameters ranging from 2.0 to $0.063 \mathrm{~mm}$, according to the method described by Santos (2000). The sediment retained in each sieve was weighed $(0.001 \mathrm{~g})$ and quantified in percentage to obtain the granulometric fractions (coarse sand, medium sand, fine sand and silt/clay). Also, the diameter (BD) and the depth of the burrow (BDTH) were recorded using a ruler $(\mathrm{mm})$ always perpendicular to the sediment. In the laboratory, the diameter of the pellets (DBS) was measured with a precision caliper $(0.01 \mathrm{~mm})$. The dry weight of the substrate excavated from the burrows of males and females was recorded with a digital balance $(0.001 \mathrm{~g})$.

After the sediment was removed from the burrow entrance, they were filled with quick-drying cement for molds (Nassau CP-II-E-32RS), which were removed after $12 \mathrm{~h}$. Then, the molds were transported to the laboratory to be benchmarked for depth (BDTH) (mm).

The animals that presented excavation activities were transported live to the laboratory and identified, according to Magalhães (2003). For these crabs we measured with the aid of a caliper $(0.01 \mathrm{~mm})$ the carapace width $(\mathrm{CW})$, carapace length $(\mathrm{CL})$ and the length of the left and right propodus chelar ( $\mathrm{LPCl}$ and $\mathrm{LPCr}$, respectively), as well as the wet weight (P) with the aid of a digital balance $(0.001 \mathrm{~g})$. In the laboratory, the crabs were kept individually in aquariums $(40 \times 40 \times 30 \mathrm{~cm})$ and conditioned with Eichhornia crassipes macrophytes until the start of the experiment.

\section{Excavation behavior}

Eight adult crabs (four males and four females) were selected and placed individually in plastic boxes $(28 \times 46 \times 35 \mathrm{~cm})$ to analyze the excavation behavior of D. page $i$ in the laboratory. At the bottom of each plastic box, $15 \mathrm{~cm}$ of sediment from the collection site (Poranga Lake) was added.

The experiment lasted $24 \mathrm{~h}$, and during this period, the behavior of each crab was recorded. At the end of this period, the crab was removed from the box, a $2 \mathrm{~cm}$ surface layer sediment was scraped off, and a new $2 \mathrm{~cm}$ layer was added; the remainder of the sediment was maintained. This procedure was performed to avoid those excretions and marks on the sediment left by another individual, which may have affected the excavation behavior of the next crab.

Video cameras (1/4" CCTV, 480TVL, NSTC) connected to a stand positioned on top of the boxes were used to visualize crab activity during $24 \mathrm{~h}$ monitoring. Each camera was programmed to document the movements of the animals as well as to evaluate the excavation time of males and females in minutes. At the end of each experiment, the animals were returned to the collection site. The crabs were monitored daily, and $40 \mathrm{~W}$ red light bulbs were used during the night. The use of this method allowed recording the movement of the crabs and avoided influencing the behavior of these decapods (Hazlett, 1966). 


\section{Data analysis}

The normality of the data was verified by the ShapiroWilk test. The Mann-Whitney test was used to compare the biometric variables $(\mathrm{CW}, \mathrm{LW}, \mathrm{P}, \mathrm{LPCr}$ and $\mathrm{LPCl})$ of male and female crabs that exhibited excavation behavior (burrows and pellets). The size of the sediment pellets removed in front of the burrows, the diameter (BD), the depth (BDTH), the amount of sediment removed during the excavation (SR), the size of the molds of the burrows and the excavation time of males and females were also compared by a MannWhitney test. Simple linear regression analysis was used to evaluate the relationship between carapace widths $(\mathrm{CW})$ and burrow characteristics (BD, BDTH, SR and DSB). All analyses of the tests were conducted in Software R 3.4.3. ( $R$ Core Team, 2015) with a significance level of $P<0.05$.

\section{RESULTS}

\section{Burrows built in the environment}

A total of 32 specimens (15 males and 17 females) were observed in their natural habitat. There was no difference between the $\mathrm{CW}$ of males and females ( $W=$ $175, P=0.0779$ ). The $\mathrm{CW}$ size of males varied from 38.92 to $48.89 \mathrm{~mm}$, with a mean of $42.97 \pm 3.19 \mathrm{~mm}$, and in females from 35.62 to $50.43 \mathrm{~mm}(40.84 \pm 3.79$ $\mathrm{mm}$ ). Males presented CL ranging from 28.31 to 38.61 $(35.15 \pm 2.75 \mathrm{~mm})$, whereas females had CL varying between 28.07 and $42.76 \mathrm{~mm}(34.03 \pm 3.61 \mathrm{~mm})$, with no difference between the sexes $(W=165.5, P=$ $0.1567)$. The LPCf of males ranged from 10.67 to 97.00 $\mathrm{mm}$ with a mean of $31.08 \pm 18.29 \mathrm{~mm}$, and in females from 19.29 to $29.55 \mathrm{~mm}$ with a mean of $23.27 \pm 2.93$ $\mathrm{mm}$; males presented higher LPCf $(W=219, P=$ 0.0021 ). Male $\mathrm{LPCr}$ fluctuated from 17.53 to $45.50 \mathrm{~mm}$ with a mean of $36.47 \pm 6.57 \mathrm{~mm}$, and this variable ranged in female LPCr from 19.93 to $31.69 \mathrm{~mm}$ with a mean of $24.07 \pm 3.17 \mathrm{~mm}$. The LPCr was significantly higher in males ( $W=235, P=0.00001)$.

The burrow built by Dilocarcinus pagei in Lake Poranga and a burrow under construction are shown in Figures 1a and 1b, respectively. In the field, burrows had a diameter varying between 41.10 and $55.81 \mathrm{~mm}$ $(48.91 \pm 4.63 \mathrm{~mm})$ and a depth ranging from 31.66 to $145.30 \mathrm{~mm}(77.39 \pm 32.90 \mathrm{~mm})$. The diameter of sediment pellets produced by males ranged from 4.32 to $6.64 \mathrm{~mm}(5.85 \pm 0.63 \mathrm{~mm})$, and those by females varied between 4.83 and $6.83 \mathrm{~mm}(5.88 \pm 0.61 \mathrm{~mm})$. The weight of the entire substrate removed by all males and females was 1.058 and $1.926 \mathrm{~kg}$, respectively (Table 1).
Male burrows had a mean diameter greater than that of females $(W=180, P=0.0480)$, although there was no difference between both sexes neither in the depth of the burrows nor in pellet diameter $(W=103, P=$ 0.2417 and $W=131.5, P=0.8948$, respectively). On the other hand, females removed significantly more sediment than males ( $W=71, P=0.0330$ ).

Burrows presented distinct characteristics and shapes between the sexes, with female burrows showing an enlargement at the bottom forming a chamber (Fig. 1c), which was not detected in male burrows (Fig. 1d). The entries of female burrows were closed at the end of the construction with a "plug"; these burrows were characterized by a smaller opening and greater depth, forming a chamber with a greater width at the bottom. Male burrows did not present this characteristic and consisted of a simple channel. The depth of the burrows obtained from the molds for both sexes ranged from 70 to $98 \mathrm{~mm}$, with a mean of 89.12 $\pm 8.80 \mathrm{~mm}$. Male burrows ranged in depth from 70 to $92 \mathrm{~mm}(83.75 \pm 9.60 \mathrm{~mm})$, and that of females varied between 90 to $98 \mathrm{~mm}(94.50 \pm 3.31 \mathrm{~mm})$, with no significant difference between sexes $(W=1, P=$ 0.05907). Concerning the relation between carapace width $(\mathrm{CW})$ and biometric variables of the burrows: only the $\mathrm{CW} v s$. DB ratio was significantly but with a low coefficient of determination (Table 2).

\section{Excavation behavior}

In the laboratory, male and female excavations presented the same movement patterns, independent of the nocturnal or diurnal period. The main difference in digging behavior between the sexes was the entrance of the burrow with a sediment plug carried out only by females. This process of building the burrows was characterized by three stages (Fig. 2); the first and second stages of excavation being common in both sexes and only the third stage, closing the burrow with a sediment plug, was observed exclusively in females.

In the beginning, crabs touched the sediment using the right and left pereiopods to drill and analyze the texture of the sediment. The later use of the claw indicated the beginning of excavation activities. Claws were only used when the excavation of the burrow was finished; this behavior of inserting the claw had the purpose of analyzing the compaction of the surface of the sediment. After the recognition of the physical structure of the sediment, sequential movements of the second, third, fourth, and fifth pereiopods were initiated, which repeatedly perforated the sediment, making the surface more pliable, allowing removal of the upper layer of the sediment (Fig. 2a). The sediment was carried to the ventral region of the center of the body by pairs of pereiopods on both sides, always in the 
Table 1. Bioturbation values of males and females of Dilocarcinus pagei. SD: standard deviation, BDTH: burrow depth, BD: burrow diameter, DSB: diameter of sediment balls, SR: sediment removed.

\begin{tabular}{lccc}
\hline Males & Minimum & Maximum & \multicolumn{1}{c}{ Mean \pm SD } \\
\cline { 2 - 4 } BDTH $(\mathrm{mm})$ & 31.66 & 118.5 & $71.19 \pm 32.51$ \\
BD $(\mathrm{mm})$ & 43.04 & 55.81 & $50.44 \pm 4.72$ \\
DSB $(\mathrm{mm})$ & 4.32 & 6.74 & $5.85 \pm 0.63$ \\
SR $(\mathrm{g})$ & 10.40 & 169.47 & $70.57 \pm 49.13$ \\
\hline Females & Minimum & Maximum & \multicolumn{1}{c}{ Mean \pm SD } \\
\cline { 2 - 4 } BDTH $(\mathrm{mm})$ & 34.20 & 145.30 & $83.23 \pm 33.14$ \\
BD $(\mathrm{mm})$ & 41.10 & 53.25 & $47.57 \pm 4.24$ \\
DSB $(\mathrm{mm})$ & 4.83 & 6.83 & $5.88 \pm 0.61$ \\
SR $(\mathrm{g})$ & 18.53 & 189.17 & $113.30 \pm 52.55$ \\
\hline
\end{tabular}

Table 2. Regression analyses between carapace width $(\mathrm{CW})$ and biometric variables of burrows of Dilocarcinus pagei. BDTH: burrow depth, BD: burrow diameter, DSB: diameter of sediment balls, SR: sediment removed, ns: not significant, *significant values $P<0.05, R^{2}$ : coefficient of determination, $P$-value, F: test value, n: individual number.

\begin{tabular}{ccccc}
\hline & $\mathrm{CW} v s$. BDTH & CW $v s . \mathrm{BD}$ & $\mathrm{CW} v s . \mathrm{DSB}$ & $\mathrm{CW} v s . \mathrm{SR}$ \\
\hline$R^{2}$ & 0.0017 & 0.3435 & 0.0011 & 0.0002 \\
$P$ & $0.8193^{\mathrm{ns}}$ & $0.0004^{*}$ & $0.8566^{\mathrm{ns}}$ & $0.9356^{\mathrm{ns}}$ \\
$\mathrm{F}$ & 0.0531 & 15.695 & 0.0332 & 0.0066 \\
$\mathrm{n}$ & 32 & 32 & 32 & 32 \\
\hline
\end{tabular}

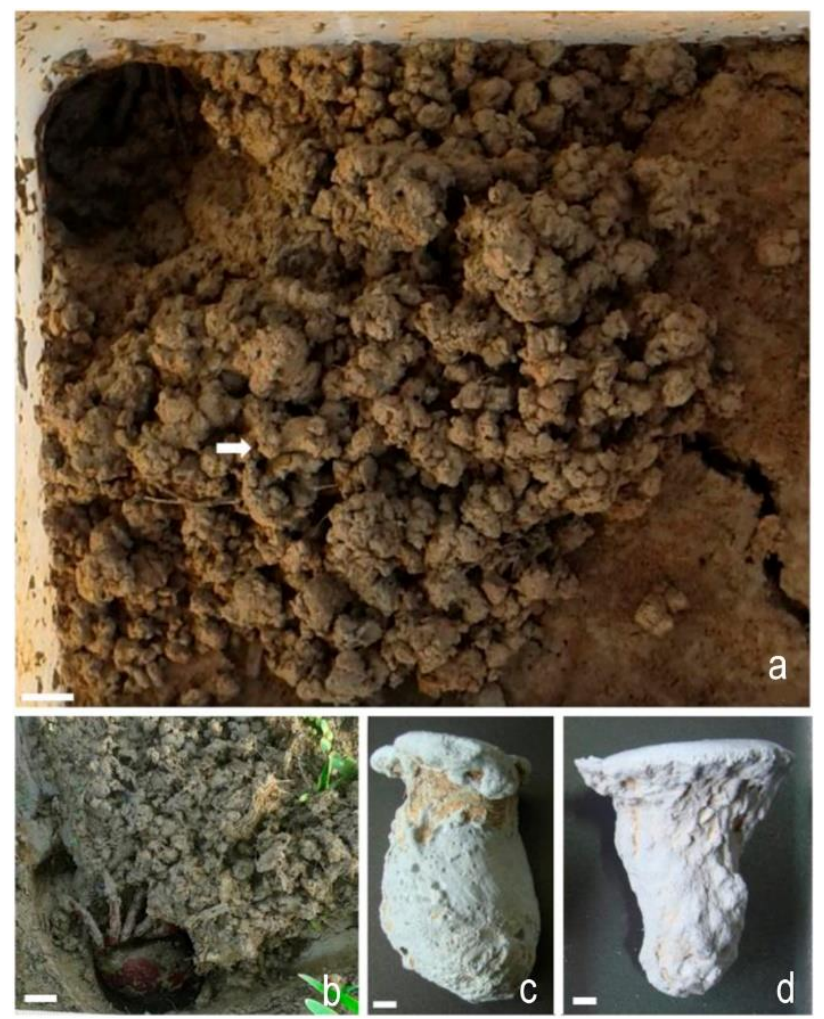

Figure 1. View of a burrow construction of Dilocarcinus pagei. a) Constructed burrow and sediment balls (setae), b) crab in the burrow excavation, c) burrow morphology of female, d) burrow morphology of male. direction of the posterior towards the anterior region (Fig. 2b). The repetition of this synchronized movement of pereiopods and claws was responsible for the formation of the pellets present on the surface of the substrate and was typical for the beginning of burrow construction. The sediment pellets were not related to foraging activity and were related to the friction of one pereiopod to the other as a way of cleaning them.

After starting the burrow construction and forming a cavity in the sediment by sequencing, drilling, and removal with the pereiopods, crabs were positioned laterally at a $90^{\circ}$ angle to the inside of the initiated burrow and continued with the sediment removal of the burrow. Instead of using the pereiopods on both sides simultaneously, crabs used only one side at a time (Fig. 2c). Except for the claws, crabs used all pereiopods facing to the inner side of the burrow. These pereiopods had the function of digging and transporting the sediment to be deposited around the opening of the burrow, while the opposite pereiopods (third, fourth and fifth) facing the outermost side of the burrow always remained inserted in the sediment to support the crab body. At this stage of excavation, the chelipeds and the second pair of pereiopods were used the most to increase the depth of the burrows and to facilitate the removal of the sediments. These claws and the second pair of pereiopods presented synchronous movements as a mechanical shovel to promote sediment removal; the third pair of pereiopods was rarely used (Fig. 2d). 
a
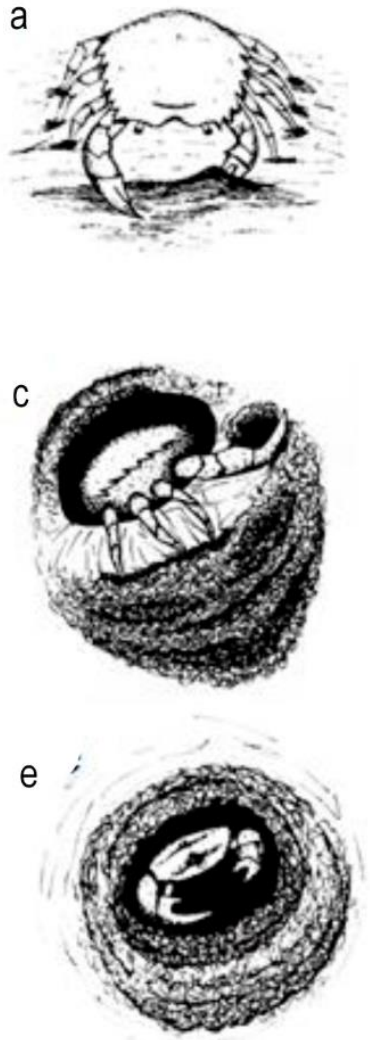

b

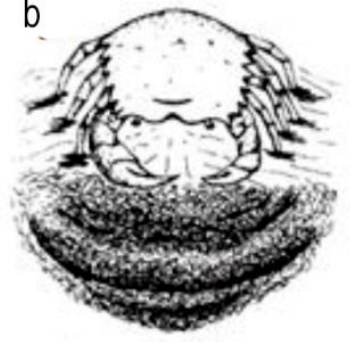

d
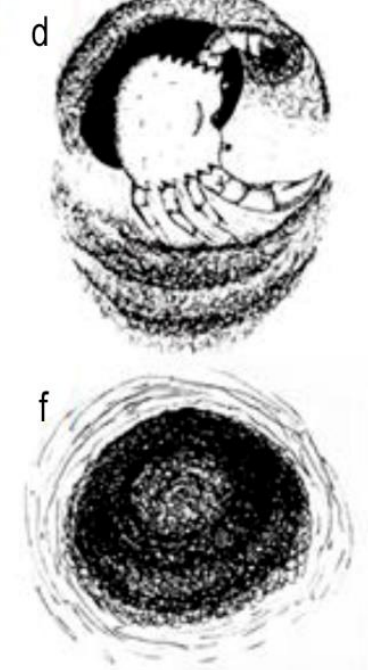

Figure 2. The process of burrow construction of Dilocarcinus pagei. a) Crab recognizes the sediment using the pereiopods (left and right), b) synchronized forward movement of pereiopods and chela in the sediment, c) crab is positioned laterally at the gallery entrance for sediment removal, d) removal and deposition of sediment around the burrow using only one of the chela in the form of a mechanical shovel, e) crab positioned at a $180^{\circ}$ angle to promote the closure of the burrow, f) gallery closed with a sediment plug at the entrance.

Females of $D$. pagei closed the burrows with a sediment plug to block the entrance. To promote the closure of the burrow, females entered the deepest part of the burrow and positioned themselves parallel to the surface of the sediment. Inside the burrow, with the upper dorsal region facing the opening, they forced the carapace parallel to the sediment to promote the enlargement, beginning the construction of the chamber (Fig. 2e). After forcing the carapace, females used the pereiopods on both sides and moved small amounts of sediment from the bottom and sides of the burrow to reduce the aperture, initiating the closing process (Fig. 2f).

After 60 days of the experiment, females were dug up, and the presence of juveniles in their abdomens was verified. These females presented aggressive behavior when they were removed, and the ventral region was

wet, different from the surface sediment that was completely dry and brittle.

The galling time ranged from 120 to $690 \mathrm{~min}$, with a mean of $298.8 \pm 204 \mathrm{~min}$, with significant differences between both sexes ( $W=0, P=0.0286$ ): males built burrows in less time (ranging from 120 to $185 \mathrm{~min}$; mean $153 \pm 32.27 \mathrm{~min}$ ) than females (260 to $690 \mathrm{~min}$; mean $445 \pm 198.41 \mathrm{~min})$. The sediment of the crab habitat used in the experiment was composed of coarse sand $(45.6 \%)$, medium sand $(24.2 \%)$, fine sand $(17.4 \%)$ and silt/clay $(12.7 \%)$.

\section{DISCUSSION}

The size of the claw of Dilocarcinus pagei did not influence the size of the burrow opening and the amount of sediment removed a pattern similar to that reported for Uca annulipes (Lim et al., 2015). The biometric relations between the size of D. pagei and the variables of the burrows did not present any significant difference. Only CW vs. BD was statistically significant, but also with a low coefficient of determination.

The beginning of the excavation process of $D$. page $i$ is different from that described for other crabs such as Cancer magister and C. productus; these species use the pereiopods simultaneously and claws to remove sediment (McGaw, 2005; Corcoran \& Merz, 2014). D. pagei uses at the beginning of the excavation only the pereiopods (Genise, 2017); this behavior serves to explore and analyze the sediment hardness, because depending on the season, floodplain soils in the Amazon can retain different levels of water (Ferreira $e t$ al., 1999), and this may facilitate or hinder the excavation process.

The sediment deposition near the entrance of the burrow also differs from mangrove crabs (GusmãoJunior et al., 2012), because the sediment is moister and fluid, due to the high presence of clay particles in it, which facilitates the withdrawal with only one of the dactyls and the second pair of pereiopods. During bioturbation, $D$. pagei rarely uses the claws, which are only used for the removal of larger amounts of sediment that form pellets under the sediment surface, which is different compared to observations from other crabs that simultaneously use pereiopods and claws for sediment removal (McLay \& Osborne, 1985; Corcoran \& Merz, 2014). Also, during the excavation, D. pagei uses only one side of the body for sediment removal, a pattern similar to that observed in Uca thayeri (Gusmão-Junior et al., 2012). This lateral position facilitates the removal of moist sediment from the interior of the burrow, promoting a lower energetic expenditure of the animal during this activity. 
Males of D. pagei took less time than females to build the burrows, probably because their burrow was simpler than those of the females. The excavation time for Uca pugilator can vary from 15 to $60 \mathrm{~min}$ (Weis \& Perlmutter, 1987). The excavation time of Ovalipes catharus is even shorter and is not different between individuals (McLay \& Osborne, 1985). The excavation time of $D$. page $i$ is also longer than in mangrove crabs such as Ucides cordatus (Nordhaus et al., 2009). This difference in the time of excavation can be related to the type of habitat, because in mangroves, crabs tend to excavate burrows in a shorter time and deeper due to the influence of tidal effect (Nordhaus et al., 2009). The crab $D$. pagei does not need to excavate burrows in a short time or deeper because daily floods do not occur as in mangrove systems. In the study site (Amazonian floodplain), the soil presents a constant decomposition of organic matter, such as roots, leaves and sticks, with mostly fractions of sand. Areas like these receive nutrients from both aquatic and terrestrial origin (Junk, 1984). Due to this sediment composition, crabs need more time to excavate the burrow. On the other hand, energy investment in digging can be rewarded in the form of permanent shelters, differing from mangrove areas, where crabs periodically maintain burrows because of the tides (Micheli et al., 1991).

The excavation behavior of $D$. pagei resulted in small balls of sediment (pellets) left at the entrance of the burrow. These pellets were observed during the construction of the burrows, both in the field and in the laboratory, and for both sexes. They were formed during the cleaning process of the claws after digging the burrows. In Ocypode quadrata, this behavior is associated with foraging activities (Robertson \& William, 1981), environmental orientation (Layne et al., 2003), reproductive strategy to attract females and marking of territory (Burford et al., 2001). Pellets formed by $D$. pagei are not associated with foraging activities, and they are a result of substrate removal during excavation, differing from what occurs with crabs of the genus Uca spp. (Crane, 1975).

The bioturbation of crabs is related to the size of the animal and the burrow constructed. Small species of the genus Uca promote less bioturbation than D. pagei (Penha-Lopes et al., 2009; Qureshi \& Saher, 2012; Machado et al., 2013). On the other hand, larger estuarine crabs such as $U$. cordatus build deeper burrows with multiple openings (De Araújo \& Calado, 2012; Pülmanns et al., 2016), and Neohelice granulata (previously Chasmagnathus granulata) (Iribarne et al., 1997; Botto \& Iribarne, 2000) promotes considerably larger bioturbation than $D$. pagei.

The morphology of the D. pagei burrows includes a single chamber (Melchor et al., 2010), differing from the burrows of Ocypode ceratophthalma, which may present more than one chambers (Chan et al., 2006). The number of chambers within the burrow is associated with courting and mating behaviors (Christy $\&$ Salmon, 1984). The burrows excavated by female $D$. page $i$ are similar to those of $U$. annulipes, characterized by having a more elongated shape at the end of the burrow, which allows the movement of crabs within these structures (Lim, 2006). Another peculiarity attributed to the females of D. pagei is that they have the habit of closing the opening of the burrows with a sediment plug. Genise (2017) reported the presence of a closed dump of $D$. pagei, but the author did not identify the individual who closed the gallery.

The behavior of closing the burrow in D. pagei is similar to that observed in Mictyris brevidactylus (Vannini, 1980): this species uses pellets to camouflage the entrance (Takeda \& Murai, 2004). Similar, Cardisoma guanhumi uses the background substrate to close the burrow entrance (Pinder \& Smits, 1993). The closure of the burrow may be due to periodic flooding, as observed for $U$. cordatus (Nordhaus et al., 2009) or to avoid predation (Koga et al., 2001). In the case of $D$. pagei, the closure may be associated with the protection of the females concerning desiccation and predators at the time of oviposition and subsequent parental care with the juveniles, since all females carried juveniles in the abdomen when the burrows were opened in the laboratory. A similar pattern of this behavior of females remaining in the burrows to protect eggs or offspring has been recorded for other decapod species (Disney, 1971; Christy, 1982).

The site where the study was conducted is an Amazonian floodplain that is influenced by the seasonality of the Amazon River (Junk, 1984). Our study was carried out during the dry season, with a reduction in the level of water promoting greater exposure of organisms (Junk \& Robertson, 1997). Also, during this field study, the presence of predatory birds was recorded, and the remains of exoskeletons of crabs were found. The sum of these effects (desiccation and predation) may have stimulated the adaptation of the excavation behavior of $D$. pagei, as reported in other crabs such as Birgus lastro (Burggren \& McMahon, 1988 ) and Chiromantes ortmanni (Gillikin \& Kamanu, 2005). Bishop (1963) found that freshwater crabs have difficulties in identifying and locating burrows, which are camou-flaged by the dry sediment of the environment, thus providing greater protection against environmental factors and predators.

The chambers in burrows of female D. pagei may also be an indication of reproductive behavior, since larger burrows, as reported in Uca spp. (Reaney \& Backwell, 2007), can maintain a more stable tempe- 
rature for egg development and influence the incubation period. The synchronization of these activities is important to ensure the survival of the crabs (Morgan \& Christy, 1995). In our study site, the release of $D$. pagei juveniles from the burrow should coincide with the end of the dry period and the beginning of the flooding of the rivers (wet period), which is usually accompanied by rainfall, becoming a favorable condition for the dispersal and survival of $D$. pagei juveniles.

\section{CONCLUSIONS}

Females promote more bioturbation than males, due to the construction of a plug closing the entrance of the burrow, and an internal chamber associated with reproduction. The pellets found around the entrance of the burrows originate from the cleaning of the pereiopods and are not associated with foraging activities. The main difference in the digging behavior between the sexes was the entrance of the burrow sealed with a sediment plug produced only by females.

\section{ACKNOWLEDGMENTS}

We thank the Coordenação de Aperfeiçoamento de Pessoal de Nível Superior (CAPES) for the scholarship granted to L.S. Fernandes, and the Conselho Nacional de Desenvolvimento Científico e Tecnológico for the grant provided to B. S. Sant'Anna (CNPq\#409910/ 2016-3). We are grateful to Maria Izabel da Silva for the illustrations and to the reviewers for their suggestions and comments about our manuscript.

\section{REFERENCES}

Backwell, P.R.Y. \& Passmore, N.I. 1996. Time constraints and multiple choice criteria in the sampling behaviour and mate choice of the fiddler crab, Uca annulipes. Behavioral Ecology and Sociobiology, 38: 407-416.

Bertness, M.D. 1985. Fiddler crab regulation of Spartina alterniflora production on a New England salt marsh. Ecology, 66: 1042-1055.

Bishop, J.A. 1963. The Australian freshwater crabs of the family Potamonidae (Crustacea: Decapoda). Australian Journal of Marine and Freshwater Research, 14: 218238.

Botto, F. \& Iribarne, O. 2000. Contrasting effects of two burrowing crabs (Chasmagnathus granulate and Uca uruguayensis) on sediment composition and transport in estuarine environments. Estuarine, Coastal and Shelf Science, 51: 141-151.
Botto, F., Valiela, I., Iribarne, O., Martinetto, P. \& Alberti, J. 2005. Impact of burrowing crabs on $\mathrm{C}$ and $\mathrm{N}$ sources, control, and transformations in sediments and food webs of SW Atlantic estuaries. Marine Ecology Progress Series, 293: 155-164.

Burford, F.R., McGregor, P.K. \& Oliveira, R.F. 2001. Male-like mudballing behavior of some female fiddler crabs (Uca tangeri). Journal of Ethology, 19: 97-103.

Burggren, W.W. \& McMahon, B.R. 1988. Biology of the land crabs. Cambridge University Press, Cambridge.

Chakrabarti, A. 1981. Burrow patterns of Ocypode ceratophthalma (Pallas) and their environmental significance. Journal of Paleontology, 55: 431-441.

Chan, B.K.K., Chan, K.K.Y. \& Leung, P.C. 2006. Burrow architecture of the ghost crab Ocypode ceratophthalma on a sandy shore in Hong Kong. Hydrobiology, 560: 43-49.

Christy, J.H. 1982. Burrow structure and use in the sand fiddler crab, Uca pugilator (Bosc). Animal Behavior, 30: 687-694.

Christy, J.H. \& Salmon, M. 1984. Ecology and evolution of mating systems of fiddler crabs (genus Uca). Biological Reviews, 59: 483-509.

Christy, J.H., Backwell, P.R. \& Goshima, S. 2001. The design and production of a sexual signal: hoods and hood building by male fiddler crabs Uca musica. Behaviour, 138: 1065-1083.

Corcoran, J.P. \& Merz, R.A. 2014. Burying efficiency and sediment preferences reveal complexities in habitat choice for Dungeness (Metacarcinus magister) and red rock (Cancer productus) crabs. Friday Harbor Laboratories Student Research Papers, 24 pp.

Crane, J. 1975. Ocypodidae: genus Uca. Fiddler crabs of the world. Princeton University Press, New Jersey.

De Araújo, M.S.L.C. \& Calado, T.C.S. 2012. Burrows architecture of the crab Ucides cordatus (Linnaeus, 1763) (Crustacea, Decapoda, Ucididae) in a mangrove swamp of Brazil. Tropical Oceanography, 39: 155165.

Disney, R.H.L. 1971. Notes on Simulium ovazzae Grenier and Mouchet (Diptera: Simuliidae) and river crabs (Malacostraca: Potamidae) and their association. Journal of Natural History, 5: 677-689.

Ferreira, S.J.F., Reichardt, K. \& Miranda, S.A.F. 1999. Características físicas de sedimentos e solos de dois lagos de várzea na Amazônia Central. Acta Amazonica, 29: 277-292.

Ferreira, T.O., Otero, X.L., Vidal-Torrado, P. \& Macías, F. 2007. Effects of bioturbation by root and crab activity on iron and sulfur biogeochemistry in mangrove substrate. Geoderma, 142: 36-46. 
Genise, J.F. 2017. Soil neighbors I: traces of other organisms in paleosols. Crustaceans and earthworms. In: Genise, J.F. (Ed.). Ichnoentomology: insect traces in soils and paleosols. Springer, Switzerland, pp. 383415.

Gillikin, D.P. \& Kamanu, C.P. 2005. Burrowing in the east African mangrove crab, Chiromantes ortmanni (Crosnier, 1965) (Decapoda, Brachyura, Sesarmidae). Crustaceana, 78: 1273-1275.

Gusmão-Junior, J.B.L., Machado, G.B.O. \& Costa, T.M. 2012. Burrows with chimneys of the fiddler crab Uca thayeri: construction, occurrence, and function. Zoological Studies, 51: 598-605.

Hazlett, B.A. 1966. The behavior of some deep-water hermit crabs (Decapoda: Paguridea) from the Straits of Florida. Bulletin of Marine Science, 16: 76-92.

Heatwole, S.J., Christy, J.H. \& Backwell, P.R. 2018. Taking a risk: how far will male fiddler crabs go? Behavioral Ecology and Sociobiology, 72: 82.

Iribarne, O., Bortolus, A. \& Botto, F. 1997. Betweenhabitat differences in burrow characteristics and trophic modes in the southwestern Atlantic burrowing crab Chasmagnathus granulata. Marine Ecology Progress Series, 155: 137-145.

Junk, W.J. 1984. Ecology of the várzea, floodplain of Amazonian white-water rivers. In: Sioli, H. (Ed.). The Amazon limnology and landscape ecology of a mighty tropical river and its basin. Springer, Cham, pp. 215243.

Junk, W.J. \& Robertson, B.A. 1997. Aquatic invertebrates. In: Junk, W.J. (Ed.). The Central Amazon floodplain. Springer Verlag, Berlin, pp. 279-298.

Koga, T., Backwell, P.R.Y., Christy, J.N., Murai, M. \& Kasuya, E. 2001. Male-biased predation of a fiddler crab. Animal Behavior, 62: 201-207.

Kristensen, E. 2008. Mangrove crabs as ecosystem engineers, with emphasis on sediment processes. Journal of Sea Research, 59: 30-43.

Layne, J.E., Barnes, W.J.P. \& Duncan, L.M.J. 2003. Mechanisms of homing in the fiddler crab Uca rapax. Information sources and frame of reference for a path integration system. Journal of Experimental Biology, 206: 4425-4442.

Lim, S.S.L. 2006. Fiddler crab burrow morphology: how do burrow dimensions and bioturbative activities compare in sympatric populations of Uca vocans (Linnaeus, 1758) and U. annulipes (H. Milne Edwards, 1837)? Crustaceana, 79: 525-540.

Lim, S.S.L., Hew, G.M.S. \& Yong, A.Y.P. 2015. Constraints imposed by the major cheliped on burrow construction in the male fiddler crab, Uca annulipes (H. Milne Edwards, 1837). Journal of Crustacean Biology, 35: 149-154.
Machado, G.B.O., Gusmao-Junior, J.B.L. \& Costa, T.M. 2013. Burrow morphology of Uca uruguayensis and Uca leptodactylus (Decapoda: Ocypodidae) from a subtropical mangrove forest in the western Atlantic. Integrative Zoology, 8: 307-314.

Magalhães, C.A. 1990. Hábitos alimentares e estratégia de forrageamento de Rosthramus sociabilis no Pantanal do Mato Grosso, Brasil. Ararajuba, 1: 95-98.

Magalhães, C. 2003. Famílias Pseudothelphusidae e Trichodactylidae. In: Melo, G.A.S. (Ed.). Manual de identificação dos Crustacea Decapoda de água doce do Brasil. Editora Loyola, São Paulo, pp. 143-287.

McGaw, I.J. 2005. Burying behaviour of two sympatric crab species: Cancer magister and Cancer productus. Scientia Marina, 69: 375-381.

McLay, C.L. \& Osborne, T.A. 1985. Burrowing behaviour of the paddle crab Ovalipes catharus (White, 1843) (Brachyura: Portunidae). New Zealand Journal of Marine and Freshwater Research, 19: 125-130.

Melchor, R.N., Genise, J.F., Farina, J.L., Sánchez, M.V., Sarzetti, L. \& Visconti, G. 2010. Large striated burrows from fluvial deposits of the Neogene Vinchina Formation, La Rioja, Argentina: a crab origin suggested by neoichnology and sedimentology. Palaeogeography Paleoclimatology and Palaeoecology, 291: 400-418.

Meysman, F.J.R., Middelburg, J.J. \& Heip, C.H.R. 2006. Bioturbation: a fresh look at Darwin's last idea. Trends in Ecology and Evolution, 21: 688-695.

Micheli, F., Gherardi, F. \& Vannini, M. 1991. Feeding and burrowing ecology of two east African mangrove crabs. Marine Biology, 111: 247-254.

Mokhlesi, A., Kamrani, E., Backwell, P. \& Sajjadi, M. 2011. Study on the behaviour of two fiddler crabs, Uca sindensis and Uca annulipes (Decapoda: Ocypodidae), in Bandar Abbas, Iran. Journal of the Marine Biological Association of the United Kingdom, 91: 245-249.

Morgan, S.G. \& Christy, J.H. 1995. Adaptive significance of the timing of larval release by crabs. American Naturalist, 145: 457-479. doi: 10.1086/285749

Natálio, L.F., Pardo, J.C., Machado, G.B., Fortuna, M.D., Gallo, D.G. \& Costa, T.M. 2017. Potential effect of fiddler crabs on organic matter distribution: a combined laboratory and field experimental approach. Estuarine, Coastal and Shelf Science, 184: 158-165.

Nordhaus, I., Diele, K. \& Wolff, M. 2009. Activity patterns, feeding and burrowing behaviour of the crab Ucides cordatus (Ucididae) in a high intertidal mangrove forest in north Brazil. Journal of Experimental Marine Biology and Ecology, 374: 104112. 
Olmos, F., Pacheco, J.F. \& Silveira, L.F. 2006. Notas sobre aves de rapina (Cathartidae, Acciptridae e Falconidae) brasileiras. Revista Brasileira de Ornitología, 14: 401-404.

Penha-Lopes, G., Bartolini, F., Limbu, S., Cannicci, S., Kristensen, E. \& Paula, J. 2009. Are fiddler crabs potentially useful ecosystem engineers in mangrove wastewater wetlands? Marine Pollution Bulletin, 58: 1694-1703.

Pinder, A.W. \& Smits, A.W. 1993. The burrow microhabitat of the land crab Cardisoma guanhumi: respiratory/ionic conditions and physiological responses of crabs to hypercapnia. Physiological Zoology, 66: 216-236.

Pinheiro, M.A.A. \& Taddei, F.G. 2005. Crescimento do caranguejo de água doce, Dilocarcinus pagei Stimpson (Crustacea, Brachyura, Trichodactylidae). Revista Brasileira de Zoologia, 22(3): 522-528.

Pülmanns, N., Mehlig, U., Nordhaus, I., Saint-Paul, U. \& Diele, K. 2016. Mangrove crab Ucides cordatus removal does not affect sediment parameters and stipule production in a one-year experiment in northern Brazil. Plos One, 11(12): e0167375. doi: 10.1371/journal.pone.0167375

Qureshi, N.A. \& Saher, N.U. 2012. Burrow morphology of three species of fiddler crab (Uca) along the coast of Pakistan. Belgian Journal of Zoology, 142: 114126.

R Core Team. 2015. R: a language and environment for statistical computing. R Foundation for Statistical Computing. [http://www.R-project.org]. Reviewed: March 20, 2018.

Reaney, L.T. \& Backwell, P.R. 2007. Temporal constraints and female preference for burrow width in the fiddler crab, Uca mjoebergi. Behavioral Ecology and Sociobiology, 61: 1515-1521.

Ribeiro, P.D., Christy, J.H., Rissanen, R. \& Kim, T.W. 2006. Males are attracted by their own courtship signals. Behavioral Ecology and Sociobiology, 61: 8189.

Ridd, P.V. 1996. Flow-through animal burrows in mangrove creeks. Estuarine, Coastal and Shelf Science, 43: 617-625.

Robertson, J.R. \& William, P.J. 1981. Deposit-feeding by the ghost crab Ocypode quadrata (Fabricius). Journal of Experimental Marine Biology and Ecology, 56: 165-177.

Sant'Anna, B.S., Andrade, D.R., Watanabe, T.T. \& Hattori, G.Y. 2014. Behavioral repertoire and substrate choice of the freshwater crab Dilocarcinus pagei Stimpson, 1861 (Decapoda, Trichodactylidae). In: Ardovini, C. (Ed.). Crabs: global diversity, behavior, and environmental threats. Nova Science Publishers, New York, pp. 57-73.
Santos, S. 2000. Influência dos fatores ambientais na abundância de Portunus spinimanus Latreille, 1819 (Crustacea, Brachyura, Portunidae) na Região de Ubatuba (SP). Ciência e Natura, 22: 129-144.

Senkman, L.E., Negro, C.L., Lopretto, E.C. \& Collins, P.A. 2015. Reproductive behaviour of three species of freshwater crabs of the family Trichodactylidae (Crustacea: Decapoda), including forced copulation by males. Marine and Freshwater Behaviour and Physiology, 48: 77-88.

Shih, H.T., Mok, H.K. \& Chang, H.W. 2005. Chimney building by male Uca formosensis Rathbun, 1921 (Crustacea: Decapoda: Ocypodidae) after pairing: a new hypothesis for chimney function. Zoological Studies, 44: 242-251.

Sinha, S. \& Pati, A.K. 2008. Circannual rhythm in spatial distribution of burrows of freshwater crab, Barytelphusa cunicularis (Westwood, 1836). Biological Rhythm Research, 39: 359-368.

Taddei, F.G \& Herrera, D.R. 2010. Crescimento do caranguejo Dilocarcinus pagei Stimpson, 1861 (Crustacea, Brachyura, Trichodactylidae) na represa Barra Mansa, Mendonça. Boletim do Instituto de Pesca, 36: 99-110.

Takeda, S. \& Murai, M. 2004. Microhabitat use by the soldier crab Mictyris brevidactylus (Brachyura: Mictyridae): interchangeability of surface and subsurface feeding through burrow structure alteration. Journal of Crustacean Biology, 24: 327339.

Vannini, M. 1980. Researches on the coast of Somalia. The shore and the dune of Sar Uanle: 27. Burrows and digging behaviour in ocypode and other crabs (Crustacea Brachyura). Monitore Zoologico Italiano, 13(1): 11-44.

Wang, J.Q., Zhang, X.D., Jiang, L.F., Bertness, M.D., Fang, C.M., Chen, K.J., Hara, T. \& Li, B. 2010. Bioturbation of burrowing crabs promotes sediment turnover and carbon and nitrogen movements in an estuarine salt marsh. Ecosystems, 13: 586-599.

Weis, J.S. \& Perlmutter, J. 1987. Burrowing behavior by the fiddler crab Uca pugilator: inhibition by the insecticide diflubenzuron. Marine Ecology Progress Series, 38: 109-113.

Williner, V. \& Collins, P.A. 2002. Daily rhythm of feeding activity of the freshwater crab Dilocarcinus pagei pagei in the Río Pilcomayo National Park, Formosa, Argentina. In: Escobar-Briones, E. \& Alvarez, F. (Eds.). Modern approaches to the study of Crustacea. Kluwer Academic/Plenum Publishers, Dordrecht, pp. 171-178. 